\title{
Abortion and women's roles in society: opinions from Tlaxcala, Mexico
}

\author{
Tia M Palermo, PhD, (1) Kate SWilson, MPH, (2) Sandra G García, ScD, ${ }^{(2)}$ \\ Claudia Díaz-Olavarrieta, $\mathrm{PhD}$. $^{(3)}$
}

\begin{abstract}
Palermo TM, Wilson KS, García SG, Díaz-Olavarrieta C. Abortion and women's roles in society: opinions from Tlaxcala, Mexico. Salud Publica Mex 2010;52:52-60.
\end{abstract}

\begin{abstract}
Objective. We aim to assess the opinions of Mexicans in the state of Tlaxcala on abortion and other topics concerning women's reproductive health and status in society. Material and Methods. We summarize opinions on abortion and women's roles in society and perform logit regressions to assess characteristics correlated with support for abortion rights. Results. A majority of respondents were against a woman's right to abortion when asked generally, but when asked about specific circumstances, a majority supported the right to abortion in five of the nine hypothetical circumstances proposed. In multivariate analysis, age, education, religion, religious service attendance, and views regarding women's roles in society had significant effects on support for the right to abortion. Conclusions. Our results demonstrate that residents ofTlaxcala view abortion as a personal decision and support a woman's right to abortion in more circumstances than currently allowed under state law.
\end{abstract}

Key words: abortion, Mexico, opinion, attitudes
Palermo TM, Wilson KS, García SG, Díaz-Olavarrieta C. El aborto y el rol de las mujeres en la sociedad: resultados de una encuesta de opinión en Tlaxcala, México. Salud Publica Mex 2010;52:52-60.

\section{Resumen}

Objetivo. Describir opiniones sobre salud sexual y reproductiva, aborto y rol social de las mujeres entre un grupo de residentes de Tlaxcala, México. Material y métodos. El análisis de regresión logística analizó características asociadas con una postura de apoyo al derecho al aborto. Resultados. La mayoría no favoreció el derecho de las mujeres a interrumpir un embarazo cuando se preguntó de manera general. Al momento de circunscribirlo a circunstancias específicas, la mayoría estuvo a favor en cinco de las nueve de situaciones hipotéticas planteadas. En análisis multivariado, edad, escolaridad, religión, asistencia a servicios religiosos y opiniones sobre el rol social femenino fueron variables significativas del apoyo que se brinda a una mujer para ejercer su derecho a interrumpir un embarazo. Conclusiones. Los residentes de Tlaxcala perciben el tema del aborto como una decisión personal y apoyan el derecho de una mujer a interrumpirlo especialmente bajo causales contempladas en la ley de Tlaxcala.

Palabras clave: México, opinión, actitudes, aborto
$\mathrm{P}$ ublic opinion on abortion varies in Mexico, and most states allow abortion only when a pregnancy results from rape or when there is a risk to the woman's life or health. Expectations about sexuality, the influence of the Catholic Church, and power differentials have led to restrictive abortion laws and limited access. ${ }^{1,2}$ Good quality, representative public opinion data is vital for abortion research and policy. We aim to assess the opinions of Mexicans in the state of Tlaxcala regarding views on abortion, reproductive health topics, and

(I) Ipas. Chapel Hill, NC, USA.

(2) Population Council. Mexico City, Mexico.

(3) Instituto Nacional de Salud Pública. Mexico City, Mexico. 
women's roles in society. We perform logit analysis and find that characteristics such as gender, education, religious affiliation and attendance, occupation, and opinions on women's roles are correlated with support for abortion rights.

\section{Background}

The framing of the abortion debate as either pro-choice or anti-abortion can be misleading because the majority opinion usually lies somewhere in between, with people supporting the right to abortion under specific circumstances. Studies conducted in the U.S. show that asking about abortion opinions in specific circumstances gives a more accurate description of opinions than asking whether someone disagrees or agrees with a woman's decision to have an abortion. These studies also show that less people than previously thought are at the extreme ends of the scale of abortion opinion. ${ }^{3,4}$

In Latin America, increased levels of education, increasing socio-economic status, paid employment, and no religious affiliation have been found to be correlated with increased support for a woman's right to abortion. ${ }^{5-13}$. Characteristics negatively correlated with support for abortion rights include religious affiliation, frequent religious service attendance, living in a rural area, and increasing parity. $5,8,11,13,14$

Previous abortion public opinion studies conducted in the U.S. and Mexico suggest that beliefs about women's roles and position in society also influence opinion about abortion. For example, those who possess more socially conservative views about women, such as believing that her primary role should be in the home as wife, mother, and caretaker also are more likely to oppose legal abortion. ${ }^{6,15,16}$ On the other hand, those who hold more progressive views about women's status in society, believing that they should have equal opportunity as men to pursue careers and education, are more likely to support legal abortion. A possible explanation for this could be that people who hold more liberal views about women's roles in society could extend this view to health, specifically, a woman's right to make her own decisions regarding fertility and abortion. In Mexico, the existing abortion opinion research tends to focus on associations between abortion opinion and sociodemographic characteristics only, such as age, gender, education, and religious practice. ${ }^{8,11,17}$ In this paper we analyze not only the correlation between abortion opinions and socio-demographic characteristics, but the correlation between such opinions and individuals' worldviews and general opinions about women's role in society (for further information on women's roles, status, and autonomy in Mexico, see Adato et al., 2000,
Idrovo and Casique, 2006, Hernández Prado et al., 2004, and Levine and Sunderland, 1993). ${ }^{18-21}$

We conducted this study in 2005 in Tlaxcala, which had a population of 1072311 at the time. The state's population represents 1 percent of the total population of Mexico. ${ }^{22}$ Compared to 40 percent nationally, 76 percent of the population of Tlaxcala lives in poverty. ${ }^{23}$ We chose Tlaxcala for our survey due to its proximity to Mexico City and because abortion is legal in fewer circumstances than in other states (only pregnancy resulting from rape, serious risk to the life or health of the woman, and an accident/fall that could induce miscarriage). Currently, Tlaxcala's abortion laws are similar to those that existed in Mexico City prior to its legalization of first trimester abortions in April 2007. Additionally, Tlaxcala has a high rate of urban poverty and demographic conditions that put women at a disadvantage. For example, women make up 66 percent of the illiterate population and the maternal mortality ratio is higher than the national average: 68.3 versus 63.3 deaths per 100000 live births. ${ }^{24}$

\section{Material and Methods}

\section{Survey}

Five organizations, including Catholics for a Free Choice (CDD); Gender Equity: Citizenship, Work, and Family; the Information Group on Reproductive Choice (GIRE); Ipas; and the Population Council, contributed to the design of the Opinion Survey in Urban Zones in Tlaxcala, 2005, which was carried out by Health and Demographic Investigation (Insad). Pilot testing was conducted in September 2005.

We used a multi-stage probability sampling methodology, with Geostatistic Areas (AGEBs), which were created during the General Census of Population and Dwellings 2000, as the primary sampling units. We randomly selected 950 dwellings in the cities of Tlaxcala and Apizaco. In the final stage, we chose one person in each household, with all permanent residents over the age of 18 having an equal probability of being chosen. A total of 950 households were sampled (475 in each city). The margin of error for point estimates is \pm 3 percent $(\mathrm{CI}$ 90 percent).

Our survey includes questions regarding opinions on women's status in society, support for abortion rights, and knowledge about abortion laws and drugs that induce abortion such as misoprostol. In order to assess an individual's support for a woman's right to abortion we asked respondents whether or not they agreed with the practice in any of the following nine circumstances: when the pregnancy is a result of rape; when 
the woman's life is in danger; when the woman's health is at risk; when the woman lacks economic resources; when the woman is a single mother; when the woman is a minor; when the fetus has congenital, physical, or mental defects; when the woman is developmentally disabled; and whenever the woman decides.

Other questions we asked in the survey included whether or not respondents had heard of emergency contraception (EC) and whether they knew someone who had had an abortion. We also asked opinions on women's roles in Mexican society. We wanted to explore if there is an association between traditional roles for women (marriage, child rearing, etc.) and holding more liberal views on reproductive health and abortion.

\section{Data analysis}

We entered, organized, and coded all data in SPSS (version 13.0, Chicago, IL, USA) and then converted it to STATA (version 9.1 College Station, TX, USA) for statistical analysis.

We summarized respondents' opinions and knowledge on a range of sexual and reproductive health topics, as well as women's roles in society, and performed logit regression to assess characteristics correlated with increased support for abortion rights. The dependent variable in this analysis is a dichotomous variable indicating a high level of support for abortion rights on an index.

In the base model, we controlled for gender, age, marital status, level of education, religious affiliation, frequency of religious attendance, and occupation. In a second regression, we included additional controls such whether the respondent has heard of emergency contraception, whether the respondent thinks that women will use abortion as a first option against unwanted pregnancy if it were to become legalized in Mexico, whether the respondent thinks a woman's main goal in life should be to study, and whether the respondent would advise his or her daughter to remain a virgin until marriage. A wealth index was also tested but was not statistically significant, so this variable was not included in the final regressions.

Standard errors are adjusted for clustering at the primary sampling unit level in the multivariate analysis. While weights were used for summary analysis, we did not use weights in the logit regressions in order to increase the power of our analysis.

\section{Measures}

We constructed an index of abortion support by summing the total number of circumstances in which the respondent supports* a woman's right to abortion (ranges from 0 to 9). We also constructed an alternative index using principal-components analysis to derive weights, as done in Filmer and Pritchett (2001) for the construction of a wealth index. ${ }^{25} \mathrm{We}$ validated the factor index against the linear scale, and they moved together. Theory suggests that an abortion support index would not be interval-level, as the distance on the scale between supporting abortion rights in one and two circumstances is not necessarily the same distance as the difference between six and seven circumstances, and so forth. We created variables equal to 1 if the respondent falls into the top tercile of abortion support and zero otherwise for each of the indices separately. Logit analysis conducted with both of these variables resulted in similar results. The analysis presented below uses the dichotomous variable created from the factor index.

Age was grouped into three categories (18 to 24, 25 to 40,41 to 60 , and over 65). Dummy variables are created for each age group and the 25 to 40 group is the reference group in the logit regression. Marital status was categorized as in union, married (the reference group), single, and separated/divorced/widowed, with dummy variables representing each category. The last category was grouped in this manner because the number of respondents in each of the three categories was too small to merit inclusion separately. We created the three following dummy variables for education: low (equal to one if the respondent had less than complete secondary education and zero otherwise), medium (equal to one if respondent completed secondary or preparatory school or a technical degree and zero otherwise), and high (equal to one if respondent had some college or higher and zero otherwise). Religious affiliation was classified as Catholic (reference group), other religion, and non-religious. Religious attendance was classified as weekly or more (reference group), monthly, or special occasions/never; dummy variables were created for each category. Occupation was classified as employed (reference group), student, retired/ disabled, unemployed, and homemaker.

We created a variable with a value equal to one if the respondent has heard of emergency contraception and zero otherwise for inclusion in the second model,

\footnotetext{
* Respondents who answered "do not know" when asked whether they supported abortion in each circumstance were classified as not supporting abortion. The percentages in this category are as follows: $3.55 \%$ for risk to woman's life, $3.66 \%$ for risk to woman's health, $4.63 \%$ for pregnancy due to rape, $1.72 \%$ for economic reasons, $1.51 \%$ when the woman is single, $2.26 \%$ when the woman is a minor, $4.52 \%$ when the fetus has congenital, physical, or mental defects, $2.16 \%$ whenever the woman decides, and $5.28 \%$ when the woman is developmentally disabled.
} 
which includes opinions and knowledge. To represent the opinions included in this model (believes women will use abortion as a first option against unwanted pregnancy if legalized, believes a woman's main goal in life should be to study, and would advise daughters to remain virgins until marriage), we created dummy variables, where the value is equal to one if the respondent holds the reference opinion and zero otherwise.

\section{Results}

Of the 950 dwellings sampled, we obtained 937 household interviews, and from those, 929 complete individual interviews, giving us a response rate of $97.8 \%$. The sample was further restricted to individuals with non-missing values for all variables included in this analysis, resulting in a final sample size of 877.

\section{Participant characteristics}

The weighted sample was $54 \%$ female. Twenty-two percent were between the ages of 18 and 24 , and $46 \%$ of respondents were between the ages of 25 and 40 (Table I). Married respondents made up $51 \%$ of the sample, while $13 \%$ were in union and $27 \%$ were single. An additional 9\% were separated, divorced, or widowed. Forty-seven percent of the sample had medium levels of schooling, and 30\% had high levels.

A majority was Catholic (86\%), 7\% identified with a religion other than Catholic, and $8 \%$ were not religious. Forty-five percent attended church (any religion) weekly or more, $31 \%$ attended monthly, and $24 \%$ attended only on special occasions or never. Homemakers made up $19 \%$ of the sample, and employed respondents were the majority $(60 \%)$.

\section{Opinions and knowledge on reproductive health topics and women's roles in society}

A large majority (88\%) believed that women would use abortion as the first option against unwanted pregnancy if abortion were to be legalized in Mexico (Table II). Thirteen percent indicated that they knew of a medication that can induce abortion, while 15\% knew someone who has had an abortion.

When asked about a woman's and the fetus' rights during pregnancy, $90 \%$ believed that the fetus has equal rights during pregnancy (Table II). However, $72 \%$ believed that the woman's life should be saved in extreme cases where a choice had to be made.

Twenty-eight percent of respondents thought that studying should be a woman's most important achievement in life (Table II). Twelve percent of the
Table I

Participant Characteristics ( $\mathrm{N}=\mathbf{8 8 7}$ ), Weighted. Tlaxcala, Mexico, 2005

$$
\text { Characteristic Proportion }
$$

Gender

\begin{tabular}{ll} 
Female & 0.54 \\
\hline Male & 0.46
\end{tabular}

Age

\begin{tabular}{ll}
18 to 24 & 0.22 \\
\hline 25 to 40 & 0.46 \\
\hline 41 to 65 & 0.25 \\
\hline over 65 & 0.07
\end{tabular}

\begin{tabular}{ll}
$\begin{array}{ll}\text { Marital status } \\
\text { Married }\end{array}$ & 0.51 \\
\hline In union & 0.13 \\
\hline Single & 0.27 \\
\hline Separated/divorced/widowed & 0.09
\end{tabular}

Education

\begin{tabular}{ll} 
Low & 0.23 \\
\hline Medium & 0.47 \\
\hline High & 0.30
\end{tabular}

Religion

\begin{tabular}{ll} 
Catholic & 0.86 \\
\hline None & 0.08 \\
\hline Other & 0.07
\end{tabular}

Religious attendance

\begin{tabular}{ll} 
Weekly & 0.45 \\
\hline Monthly & 0.31 \\
\hline Special occasions only/never & 0.24
\end{tabular}

Occupation

\begin{tabular}{ll} 
Employed & 0.60 \\
\hline Student & 0.09 \\
\hline Retired, disabled & 0.04 \\
\hline Unemployed & 0.07 \\
\hline Homemaker & 0.19 \\
\hline
\end{tabular}

sample thought that a woman's main goal should be to work or be successfully professionally, while a third of the sample gave more traditional answers regarding a woman's role, such as have a home $(13 \%)$, ensure the well-being of her family and children (10\%), have children $(6 \%)$, and get married $(2 \%)$. 
Table II

Opinions and KNOWLedge on Reproductive health topics (N=887), Weighted.Tlaxcala, MeXico, 2005

\begin{tabular}{|c|c|}
\hline Opinion & Proportion \\
\hline $\begin{array}{l}\text { Believes that if abortion is legalized in Mexico, more women } \\
\text { will use it as first option against unwanted pregnancy }\end{array}$ & 0.88 \\
\hline Knows of a medication that can induce abortion & 0.13 \\
\hline Knows someone who has had an abortion & 0.15 \\
\hline Would advise daughters to remain virgins until marriage & 0.66 \\
\hline $\begin{array}{l}\text { Believes the fetus has the same rights as the woman during } \\
\text { pregnancy }\end{array}$ & 0.90 \\
\hline $\begin{array}{l}\text { Believes the woman's life should be saved in extreme case in } \\
\text { which a choice had to be made }\end{array}$ & 0.72 \\
\hline $\begin{array}{l}\text { Thinks it is acceptable for a minor to obtain an abortion after } \\
\text { becoming pregnant by boyfriend }\end{array}$ & 0.15 \\
\hline Believes there should be a month-limit for abortions & 0.65 \\
\hline \multicolumn{2}{|l|}{$\begin{array}{l}\text { Believes the following should be a woman's most important } \\
\text { goal in life: }\end{array}$} \\
\hline Study & 0.28 \\
\hline To be self-sufficient & 0.16 \\
\hline Have a home & 0.13 \\
\hline Work, to be successful professionally, have a career & 0.12 \\
\hline The well-being of her family and children & 0.10 \\
\hline Achieve whatever she proposes & 0.09 \\
\hline Have children & 0.06 \\
\hline Balance family with personal development & 0.03 \\
\hline Get married & 0.02 \\
\hline Other & 0.02 \\
\hline \multicolumn{2}{|l|}{ Reasons why respondent is against abortion (if applicable): } \\
\hline $\begin{array}{l}\text { Needs to accept consequences/be responsible/she } \\
\text { took the risk }\end{array}$ & 0.64 \\
\hline $\begin{array}{l}\text { Fetus is innocent/no justification/disagree/religious } \\
\text { reasons }\end{array}$ & 0.19 \\
\hline $\begin{array}{l}\text { There are ways to avoid pregnancy/should have used } \\
\text { contraceptive }\end{array}$ & 0.09 \\
\hline Other & 0.08 \\
\hline \multicolumn{2}{|l|}{ Most important opinions in deciding laws on abortion: } \\
\hline Women & 0.63 \\
\hline Catholic Church & 0.03 \\
\hline Medical community & 0.07 \\
\hline Society & 0.22 \\
\hline Political parties & 0.01 \\
\hline Civic organizations that support women's rights & 0.04 \\
\hline
\end{tabular}

Sixty-six percent of respondents would advise their daughters to remain virgins until marriage (Table II).

Only 15\% of respondents believed that it is acceptable for an adolescent to obtain an abortion if she becomes pregnant by her boyfriend. Of respondents who were against abortion in this circumstance, $64 \%$ said their reasons were because the woman needs to accept the consequences, take responsibility, or because she took the risk (Table II). Only 19\% stated their reasons in terms of religious beliefs, fundamental disagreement with abortion, or because they thought the fetus was innocent.

When asked whose opinion should be most important in determining laws on abortion, 63\% said women's and $22 \%$ said society in general, while $7 \%$ said the medical community and only 3\% said the Catholic Church (Table II). Twenty-two percent thought that society's opinion in general was most important.

On average, respondents supported abortion rights in four circumstances out of nine (Table III). The five circumstances with majority support for a woman's right to abortion were when the woman's life is in danger (83\%); risk to the woman's health $(79 \%)$; congenital defects, mental, or physical defects $(55 \%)$; pregnancy resulting from rape $(53 \%)$; and when the woman is developmentally disabled (52\%) (Table III). Women had higher levels of support for abortion rights than men in the following circumstances: risk to the woman's life; pregnancy as a result of rape; lack of economic resources; congenital, mental, or physical defects; and when the woman is developmentally disabled. Conversely, men had higher support for abortion rights when the woman is a minor.

Despite varying opinions on circumstances under which they support abortion, $79 \%$ of respondents believed that medical schools should teach their students safe abortion techniques. However, this percentage is still lower than the percentage of respondents that support abortion in the case of risk to the woman's life (results not shown).

\section{Multivariate analysis of abortion opinion}

In the logit regressions, women were more likely to support the right to abortion than were men (Table IV). There were no significant effects of age or marital status on support for abortion rights. Increasing levels of education had a positive effect; respondents in the low education category were less likely than those in the middle education category to support a woman's right to an abortion, while those with high levels of education were more supportive. Religions affiliation and frequency of attendance were also significant. As compared to Catholics, nonreligious respondents were more supportive of abortion rights, while there were no significant differences between Catholics and respondents of other religions. Respondents who attended church services monthly or on special occasions only were more supportive of abortion rights than those who attend weekly. Homemakers were less supportive of abortion rights than respondents in other occupation categories. 
Table III

\section{Circumstances in Which Respondents SUPPORT A WOMAN's RIGHT tO ABORTION (N=887), Weighted. Tlaxcala, Mexico, 2005}

\begin{tabular}{llll} 
& & Proportion \\
& & Males & Total \\
\cline { 2 - 4 } Some or all circumstances & Females & 0.90 & 0.92 \\
\hline No circumstances & 0.93 & 0.10 & 0.08 \\
\hline Risk to the woman's life & 0.07 & 0.83 & 0.83 \\
\hline Risk to the woman's health & 0.84 & 0.79 & 0.79 \\
\hline Rape & 0.79 & 0.50 & 0.53 \\
\hline Lack of economic resources & 0.55 & 0.10 & 0.12 \\
\hline Woman is a single mother & 0.13 & 0.04 & 0.04 \\
\hline Woman is a minor & 0.04 & 0.18 & 0.17 \\
\hline Congenital, physical, or mental defects & 0.16 & 0.52 & 0.55 \\
\hline When the woman is developmentally disabled & 0.58 & 0.46 & 0.52 \\
\hline Whenever a woman decides & 0.57 & 0.25 & 0.25 \\
\hline Average number of circumstances support abortion* & 0.25 & 3.68 & 3.81
\end{tabular}

In the second model, beliefs regarding women's achievements in life and sexual behavior had significant effects on abortion opinion. Believing that a woman's most important goal in life is to study was correlated with increased support for abortion rights. Respondents who would advise their daughters to remain virgins until marriage were less likely to support these rights. Having heard of emergency contraception had no effect on support for abortion, nor did believing abortion would be the first recourse against unwanted pregnancy if legalized. After controlling for these additional opinions, statistically significant coefficients in the base model attenuated slightly but remained significant and the direction of the effects were consistent in both models.

\section{Discussion}

Increased education, no religious affiliation, and being female had positive effects on support for a woman's right to an abortion, whereas frequent religious attendance, being a homemaker, being Catholic, and traditional views of women's status in society contributed to less supportive views.

The finding that a majority of respondents thought that the Catholic Church should not have a voice in abortion legislation reflects the laicism in Mexican culture. Blancarte argues that laicism has long existed in Mexico. ${ }^{26}$ Because of this belief in a separation of church and state, Mexican Catholics may still support ideas such as divorce, the use of contraceptives, and abortion. Secularization is evident in the results of this study. While the vast majority of participants identified as Catholics and reported attending mass, they do not necessarily abide by the Church's teachings in all aspects of their lives.

Despite the fact that more respondents identified studying as a woman's main achievement in life than any other goal, close to a third of respondents gave answers representing more traditional roles for women such as having a home, having children, getting married, and ensuring the well-being of their families and children. A majority of respondents also thought their daughters should remain virgins until marriage. These views suggest that many respondents view sex as appropriate only within marriage and not in the broader context of sexual and reproductive rights. The former view does not promote open discussion regarding prevention of unwanted pregnancies, nor does it facilitate public discussion on abortion. However, over $90 \%$ of respondents supported sex education in public schools 
Table IV

SUPPORT FOR ABORTION, LOGIT REGRESSION ( $\mathrm{N}=887$ ). Tlaxcala, Mexico, 2005

\begin{tabular}{ccc} 
& $(I)$ & $(2)$ \\
Female & OR $(95 \% \mathrm{Cl})$ & OR $(95 \% \mathrm{Cl})$ \\
\hline & $1.90^{\ddagger}$ & $\mathrm{I} .8 \mathrm{I}^{\ddagger}$ \\
\hline$(1.3 \mathrm{I}-2.49)$ & $(\mathrm{I} .26-2.36)$
\end{tabular}

Age (ref $=25$ to 40$)$

\begin{tabular}{ccc} 
I8 to 24 & 0.69 & 0.65 \\
\hline & $(0.45-0.93)$ & $(0.4 \mid-0.89)$ \\
\hline $4 I$ to 65 & 1.33 & $I .26$ \\
\hline & $(0.94-I .7 I)$ & $(0.9|-| .62)$ \\
\hline Over 65 & $0.7 \mid$ & 0.69 \\
\hline & $(0.1 I-I .30)$ & $(0.08-I .3 I)$
\end{tabular}

\begin{tabular}{lcc}
$\begin{array}{l}\text { Marital status (ref=married) } \\
\text { In union }\end{array}$ & 0.98 & 0.88 \\
\hline & $(0.62-1.35)$ & $(0.53-1.23)$ \\
\hline Single & 1.06 & 0.98 \\
\hline & $(0.68-1.44)$ & $(0.62-1.34)$ \\
\hline Separated/divorced/widowed & 0.99 & 0.94 \\
\hline & $(0.49-1.50)$ & $(0.48-1.40)$
\end{tabular}

Education (ref=primary)

\begin{tabular}{ccc} 
Low & $0.32^{\ddagger}$ & $0.36^{\ddagger}$ \\
\hline High & $(0.18-0.46)$ & $(0.19-0.52)$ \\
\hline & $1.62^{\ddagger}$ & $1.49^{*}$ \\
\hline
\end{tabular}

Religion (ref=Catholic)

\begin{tabular}{ccc} 
None & $2.65^{\ddagger}$ & $2.40^{\ddagger}$ \\
\hline Other & $(1.30-3.99)$ & $(1.11-3.69)$ \\
\hline & 1.18 & 1.16 \\
\hline & $(0.71-1.64)$ & $(0.72-1.60)$
\end{tabular}

\begin{tabular}{lcc}
$\begin{array}{l}\text { Religious attendance (ref=weekly) } \\
\text { Monthly }\end{array}$ & $1.59^{*}$ & $1.46^{*}$ \\
\hline & $(1.10-2.07)$ & $(1.00-1.92)$ \\
\hline Special occasions only/never & $2.30^{\ddagger}$ & $2.1 I^{\ddagger}$ \\
\hline & $(I .4 I-3.19)$ & $(1.23-2.99)$
\end{tabular}

\begin{tabular}{lcc}
$\begin{array}{l}\text { Occupation } \\
\text { Student }\end{array}$ & $1.4 \mathrm{I}$ & $\mathrm{I} .27$ \\
\hline & $(0.47-2.35)$ & $(0.40-2.13)$ \\
\hline Retired, disabled & 0.85 & 0.85 \\
\hline & $(0.18-\mathrm{I} .52)$ & $(0.15-1.55)$ \\
\hline Unemployed & 0.68 & 0.83 \\
\hline & $(0.30-\mathrm{I} .07)$ & $(0.35-\mathrm{I} .30)$ \\
\hline Homemaker & $0.60^{*}$ & $0.59^{*}$ \\
\hline & $(0.37-0.82)$ & $(0.37-0.8 \mathrm{I})$
\end{tabular}

Other opinions/knowledge Has heard of EC 0.95

\begin{tabular}{lc}
\hline & $(0.70-I .20)$ \\
\hline Abortion first option & 0.6 \\
\hline Women's goal to study & $(0.3 \mid-0.89)$ \\
\hline & $1.72^{\ddagger}$ \\
\hline Daughters to remain virgins & $(1.22-2.22)$ \\
\hline & $0.55^{\ddagger}$ \\
\hline
\end{tabular}

* significant at $5 \%$ level

$\ddagger$ significant at $1 \%$ level (results not shown), which shows support for open dialogue on the prevention of unwanted pregnancy and sexually transmitted infections. In more developed countries, where women have higher average education levels and presumably higher status, abortion laws tend to be more liberal, and our study provides evidence that increasing levels of education are also related to opinions on abortion in Mexico.

Respondents holding traditional views on women's status in society tended to have lower support for a woman's right to abortion. Homemakers averaged lower scores than respondents who worked, and respondents who would advise their daughters to remain virgins until marriage scored lower than those who would not. Alternatively, those who believed that studying was the most important thing for a woman to accomplish in life scored higher than those holding other opinions on what a woman's goal in life should be. These results support the hypothesis put forth in Luker, a study conducted on abortion activists that concluded that supporters and opponents of abortion hold different worldviews. ${ }^{16}$ The former group supports women's roles in society such as studying and careers and therefore the decision to delay motherhood, while the latter values motherhood as a woman's most important accomplishment and primary identity. Luker argues that the stance against abortion is not only about rights of the fetus but also represents a reaction to a perceived threat to woman's traditional position in society. Though the results of this study support this hypothesis to some degree, they also suggest far more middle ground exists than Luker concluded.

Certain circumstances had majority support for abortion, such as when the woman's life is in danger or her health is at risk, when the pregnancy is a result of rape, and when there are physical or mental defects of the fetus. However, far fewer respondents supported abortion for reasons that they attributed to a lack of responsibility on the woman's part. Very few supported abortion when presented with the scenario of an adolescent becoming pregnant after having sex with her boyfriend. When asked their reasons for being against abortion in this case, most respondents gave their reason in terms of punishing the adolescent for being irresponsible. Only a minority said they were against abortion because they believed the fetus to be an innocent creature or for religious reasons.

Some of the contradictions among respondents' opinions on abortion may be due to underlying ambivalence around these issues. For example, the percentage of respondents who thought that doctors should be trained to perform safe abortions was lower than the percentage that supported abortion in cases such as 
endangerment of the woman's life or risk to her health. In addition, respondents holding more conservative general views on abortion moderated their opinions on abortion when asked about specific circumstances. Most respondents viewed the fetus as having the same rights as the woman during a pregnancy. Yet most respondents would opt to save the woman over the fetus if they had to make a choice, which suggests that when presented with a concrete situation, respondents were more likely to relate to the woman's perceptive as partners, friends, or the woman themselves. Another possibility is that living in a state that is relatively conservative with respect to abortion, many respondents simply may not have been exposed to nuanced arguments about the issues or otherwise had the opportunity to formulate clear opinions about circumstances in which abortion should be legal. ${ }^{1}$

Our study was carried out at a time when the Tlaxcala state legislature was just beginning to consider liberalizing the abortion laws and public awareness raising and debate was minimal. In places such as the United States, where abortion opinion has been extensively studied and abortion is a heated topic of public debate that often arises in political campaigns, the general public is more accustomed to making distinctions among specific circumstances in which an abortion may be justified, and they may have given more thought to the issues surrounding abortion. 3,4,27,28,29 Whether the apparent contradictions in public opinion are due to underlying ambivalence, lack of exposure to these issues, or a combination merits further investigation. Regardless, these findings highlight the importance of asking several general and specific questions about abortion in order to probe the full range of opinions and related inconsistencies around this complex issue.

Despite the varying opinions on abortion shown in this survey and the fact that many people in Tlaxcala oppose abortion in several of the proposed circumstances, respondents still tend to view abortion as a personal decision. Evidence of this includes the fact that a majority of both men and women believe that the decision to terminate a pregnancy is that of a woman alone and that the stance of the Catholic Church should have no bearing on the drafting of abortion legislation.

In Mexico's changing social and political climate high quality representative public opinion surveys could not be timelier. In a state where abortion is legal in fewer circumstances than other states in Mexico and neighboring Mexico City, our results show that the public in Tlaxcala has more liberal opinions on abortion than current laws in that state, meaning there is support for a woman's right to abortion in more circumstances than are currently permitted under the law. Future re- search should explore abortion opinion in other states in Mexico and among key interest groups such as lawyers, health care providers, and women of reproductive age. Legislatures in Tlaxcala and throughout Mexico, who otherwise may be wary of public opinion or political repercussions, can use these results to strengthen their cases for liberalization of abortion laws. In addition, women's rights groups can use this public opinion data to develop evidence-based advocacy strategies in favor of legalization of abortion.

\section{References}

I. Kulczycki A.The abortion debate in Mexico: realities and stalled reform. Bull Lat Am Res 2007; 26(I): 50-68.

2. Lamas M, Bissell BS. Abortion and politics in Mexico: context is all. Reprod Health Matters 2000; 8 (16): 10-23.

3. Cook EA, Jelen TG, Wilcox C. Measuring public attitudes on abortion: methodological and substantive considerations. Fam Plann Perspec 1993; 25(3): I I8-2I, 145.

4. Bumpass LL. The measurement of public opinion on abortion: the effects of survey design. Fam Plann Perspec 1997; 29(4): I77-I80.

5. García S, Tatum C, Becker D, Swanson K, Lockwood K, Ellertson C. Policy implications of a national public opinion survey on abortion in Mexico. Reprod Health Matters 2004; I2(24 Supplement):65-74.

6. Yam EA, Garcia SG, Dries-Daffner I.Abortion Opinion Research in Latin America and the Caribbean:A Review of the Literature. Stud Fam Plann 2006; 37(4): 225-240.

7. Bailey PE, Bruno ZV, Bezerra MF, Queirós I, Oliveira CM. Adolescents' decision-making and attitudes towards abortion in North-East Brazil. J Biosoc Sci 2003; 35, 7I-82.

8. Becker D, García S, Larsen U. Knowledge and opinions about abortion law among Mexican youth. Int Fam Plann Perspect 2002; 28(4):205-2I 3.

9. Alves-Duarte G, Alvarenga AT, Duarte-Osis MJM, Faúndes A, Hardy E. Male perspective on induced abortion. Rev Saúde Pública 2002;36(3): 27I-277.

10. Cesar JA, Gomes G, Horta BL, de Oliveira AK, de O Saraiva AK, Pardo DO, et al. Women's opinions on abortion legalization in a county in Southern Brazil. Rev Saúde Pública 1997;31(6):566-57I.

I I. Casanueva E, Lisker R, Carnevale A,Alonso E. Attitudes of Mexican physicians toward induced abortion. Int J Gynecol Obstet 1997;56:47-52. I2. Núñez-Fernández L, Shrader-Cox E, Benson J. Encuesta de opinión sobre el aborto en la Ciudad de México. Salud Publica Mex 1994;36:36-45. 13. Duarte-Osis MJ, Hardy E, Faúndes A, Alves G, Balarezo G. Women's Opinions on Circumstances Under Which Hospitals Should Perform Abortions. Cad Saúde Públ 1994;10(3):320-330.

14. Gogna M, Romero M, Ramos S, Petracci M, Szulik D.Abortion in a restrictive legal context:The views of obstetrician-gynaecologists in Buenos Aires,Argentina. Reprod Health Matters 2002; I0(19): I28-I 37. 15. Strickler J, Danigelis N. Changing Frameworks in Attitudes toward Abortion. Sociological Forum 2002; I7(2): 187-201.

16. Luker K.Abortion and the Politics of Motherhood. New York: University of California Press, 1984.

17. Camp RA.The cross in the polling booth: religion, politics, and the laity in Mexico. Lat Am Res Rev 1994;29(3):69-100.

18. Adato M, de laBriere B, Mindek-Dubravka, Quisumbing A.The Impact of PROGRESA on Women's Status and Intrahousehold Relations. Final Report, International Food Policy Research Institute 2000. [Accessed July 14, 2008]. Available at: www.ifpri.org 
19. Idrovo AJ, Casique I. El empoderamiento de las mujeres y la esperanza de vida al nacer en México. Rev Panam Salud Publica 2006; 20(I): 29-38.

20. Hernández-Prado B, Urquieta-Salomón JE, Ramírez-Villalobos MD, Figueroa JL. Impact of Oportunidades on the Reproductive Health of its Beneficiary Population. External Evaluation of the Impact of the Human Development Program Oportunidades. México: Instituto Nacional de Salud Pública, 2004.

21. Levine S, Sunderland-Correa C. Dolor y Alegría:Women and Social Change in Urban Mexico. Madison:The University of Wisconsin Press, 1993. 22. CONAPO 2007. Consejo Nacional de Poblacion: situación demográfica de Mexico. [Accessed July 14, 2008]. Available at: http://www. conapo.gob.mx/publicaciones/inicios/00I.htm

23. INEGI, XII General Population and Dwelling Census 2000:Tlaxcala. [Accessed July 14, 2008]. Available at: http://www.e-mexico.gob.mx/wb2/ eMex/eMex_INEGI_XII_Censo_general_de_poblacion_y_vivie
24. Tapia A, Garrido F, Gómez O. Salud: México 200I-2005. Información estratégica por entidad federative. México: Secretaria de Salud, 2006. 25. Filmer D, Pritchett LH. Estimating Wealth Effects without Expenditure Data—or Tears:An Application to Educational Enrollments in States of India. Demography 200 I; 38(I): I I5-I32.

26. Blancarte R. Laicidad y secularización en México. Estud Sociol 200 I; 19(57):843-855.

27. Shaw GM.The Polls_-Trend. Public Opinion Quarterly 2003; 67(3): 407-429.

28. Mouw T, Sobel M. Culture Wars and Opinion Polarization:The Case of Abortion. Am J Sociol 200 I; 106(4):913-943.

29. Henshaw SK, Martire G. Morality and Legality. Fam Plann Perspect 1982; I4(2):53-55,59-60. 